\title{
Laporan baru tungau Tarsonemus bilobatus Suski dan karakter utama tungau lain pada daun tanaman jeruk di Pulau Jawa, Indonesia
}

\author{
New report of the mites Tarsonemus bilobatus Suski and key \\ characters of other mites on the citrus leaves in Java Island, Indonesia
}

\author{
Hendri Hermawan ${ }^{*}$, Sugeng Santoso ${ }^{2}$, Aunu Rauf ${ }^{2}$ \\ ${ }^{1}$ Balai Karantina Pertanian Kelas II Palangka Raya \\ Jalan G. Obos KM. 5,5 Menteng, Kecamatan Jekan Raya, Kota Palangka Raya, \\ Kalimantan Tengah 73112, Indonesia \\ ${ }^{2}$ Departemen Proteksi Tanaman, Fakultas Pertanian, IPB University \\ Jalan Kamper, Kampus IPB Dramaga, Bogor 16680, Indonesia
}

(diterima Juni 2020, disetujui Juni 2021)

\begin{abstract}
ABSTRAK
Jeruk merupakan salah satu komoditas unggulan di Indonesia. Salah satu masalah utama pada produksi jeruk adalah infestasi tungau. Spesies tungau telah banyak dilaporkan menyerang jeruk di dunia. Tujuan penelitian ini untuk mengidentifikasi dan mendeskripsikan karakter utama spesies tungau pada daun tanaman jeruk di Pulau Jawa, Indonesia. Pengambilan sampel dilakukan pada lokasi pertanaman jeruk dan tanaman jeruk yang berada di pekarangan rumah yang dilakukan secara purposif. Pada lokasi pertanaman yang luas, pengambilan sampel dilakukan terhadap 10 pohon jeruk yang menunjukan gejala serangan tungau. Proses identifikasi dilakukan dengan proses mounting untuk mendapatkan spesimen yang bisa diamati di bawah mikroskop compound dengan menggunakan media PVA. Total delapan spesies tungau telah dikoleksi dari 8 jenis jeruk dan 15 lokasi. Enam dari spesies yang ditemukan adalah fitofag, yaitu Panonychus citri McGregor, Eotetranychus sp., Eutetranychus sp. (Famili Tetranychidae), Brevipalpus phoenicis (Geijskes) (Famili Tenuipalpidae), Tarsonemus bilobatus Suski (Famili Tarsonemidae), dan Phyllocoptruta oleivora (Ashmead) (Famili Eriophyidae). Dua lainnya, yaitu Amblyseius sp. (Famili Phytoseiidae) dan Cheletogenes ornatus (Canestrini \& Fanzago) (Famili Cheyletidae) merupakan predator. Tungau lain yang belum teridentifikasi, yaitu tergolong Famili Tydeidae dan Winterschmidtiidae. Berdasarkan Permentan Nomor 31 Tahun 2018, Ph. oleivora merupakan OPTK. Spesies T. bilobatus merupakan temuan baru sehingga menjadi laporan pertama kali adanya spesies ini dari di Indonesia.
\end{abstract}

Kata kunci: jeruk, karantina, morfologi, OPTK, tungau

\begin{abstract}
Citrus is one of the most important fruit crops in Indonesia. One of the main problems in citrus production is mite infestation. Many mite species were reported attacking citrus around the world. This study was aimed to identify mites and describe the main characters of various species of mites on citrus in Java, Indonesia. Sampling was carried out at the location of citrus plantations and citrus plants in the yard of the house which was carried out purposively. In a large planting area, sampling was carried out on 10 citrus trees that showed symptoms of mite attack. The identification process is carried out by a mounting process to obtain specimens that can be observed under a compound microscope using PVA. Eight species of mites were collected from 8 various of citrus from 15
\end{abstract}

\footnotetext{
*Penulis korespondensi: Hendri Hermawan. Balai Karantina Pertanian Kelas II Palangka Raya, Jalan G. Obos KM. 5,5 Menteng, Kecamatan Jekan Raya, Kota Palangka Raya, Kalimantan Tengah 73112, Indonesia, Tel/Faks: 0536-3247484, 3247485,

Email: hendrihermawan@pertanian.go.id
} 
location. Six mites species were identified as phytophagous, i.e., Panonychus citri McGregor, Eotetranychus sp., Eutetranychus sp. (Family Tetranychidae), Brevipalpus phoenicis (Geijskes) (Family Tenuipalpidae), Tarsonemus bilobatus Suski (Family Tarsonemidae), and Phyllocoptruta oleivora (Ashmead) (Family Eriophyidae). Meanwhile, the other two species, Amblyseius sp. (Family Phytoseiidae) and Cheletogenes ornatus (Canestrini \& Fanzago) (Family Cheyletidae) were predators. Unidentified mites were Family Tydeidae and Winterschmidtiidae. According to Regulation No. 31 of 2018, P. citri and Ph. oleivora are quarantine pest. T. bilobatus is firstly reported in Indonesia.

Key words: citrus, mites, morphology, new report, quarantine

\section{PENDAHULUAN}

Jeruk merupakan salah satu tanaman buah utama di Indonesia karena memiliki beberapa keunggulan kompetitif dengan beberapa kriteria. Kriteria pasar menyebutkan bahwa jeruk merupakan buah yang paling disukai konsumen karena mengandung vitamin $\mathrm{C}$ tinggi, rasa yang enak, dan menyegarkan; kriteria ekonomi menyebutkan bahwa jeruk mempunyai kisaran harga yang cukup tinggi; dari segi kriteria agronomi, jeruk merupakan tanaman yang mudah ditumbuhkan dan dapat berproduksi pada kisaran lingkungan agroklimat yang luas (Ditjen Horti 2014a).

Produksi jeruk nasional pada lima tahun terakhir mengalami kenaikan dari 1.856 .092 ton (2015) menjadi 2.722.952 ton (2020) (BPS 2021). Beberapa daerah yang menjadi sentra produksi jeruk tersebar hampir di seluruh Indonesia, seperti provinsi di Pulau Sumatera, Pulau Jawa, Pulau Bali, Pulau Timor, Kalimantan, dan Sulawesi, sedangkan untuk sentra produksi di Pulau Jawa meliputi Provinsi Jawa Barat, Jawa Tengah, dan Jawa Timur (Ditjen Horti 2014b).

Tungau merupakan salah satu golongan organisme pengganggu tanaman (OPT) pada tanaman jeruk yang memiliki arti penting secara ekonomi, bahkan dalam Peraturan Menteri Pertanian Republik Indonesia Nomor 31/Permentan/KR.010/7/2018 beberapa jenis tungau dicegah masuk ke Indonesia, seperti Phyllocoptruta oleivora (Ashmead) (citrus rust mite), Eutetranychus orientalis Klein (citrus brown mite), Aculops pelekassi (Keifer) (pink citrus rust mite), dan Brevipalpus californicus (Banks) (citrus flat mite). Affandi (2007) melaporkan hasil penelitiannya terhadap kelimpahan populasi tungau pada tanaman jeruk di Solok dan diketahui terdapat enam spesies tungau fitofag, yaitu $B$. californicus, Brevipalpus obovatus Donnadieu,
Brevipalpus phoenicis (Geijskes), Tenuipalpus sp., Eotetranychus sp., dan Panonychus citri McGregor.

Pengembangan informasi tentang tungau jeruk di Indonesia ini sangat penting untuk dijadikan dasar tindakan pencegahan dan pengendalian. Informasi yang diperoleh dapat melengkapi data Badan Karantina Pertanian. Selain itu, ketersediaan deskripsi morfologi karakter utama mengenai tungau jeruk yang ada di Indonesia juga sangat diperlukan sebagai acuan dalam mengidentifikasi tungau yang berasosiasi dengan tanaman jeruk. Penelitian ini bertujuan untuk mengidentifikasi dan mendeskripsikan karakter utama spesies tungau pada daun tanaman jeruk di Pulau Jawa, Indonesia.

\section{BAHAN DAN METODE}

\section{Pengambilan sampel}

Pengambilan sampel dilakukan pada beberapa lokasi pertanaman jeruk dan tanaman jeruk yang berada di pekarangan rumah secara purposif di Pulau Jawa (Tabel 1). Pada lokasi pertanaman yang luas, pengambilan sampel dilakukan terhadap 10 pohon jeruk yang menunjukan gejala serangan tungau, sedangkan untuk di pekarangan rumah, pengambilan sampel tungau dilakukan pada semua pohon bergejala. Sepuluh pucuk dan daun yang sudah berwarna hijau tua diambil dari empat arah mata angin pada setiap pohon.

\section{Penanganan sampel}

Setiap sampel daun (pucuk dan daun yang sudah berwarna hijau tua) dimasukkan ke dalam kantong plastik bening, diberi keterangan inang dan lokasi pengambilan sampel, kemudian setelah itu disimpan dalam coolbox. Setiap sampel dicuci dengan $\pm 20 \mathrm{ml}$ alkohol $70 \%$ di dalam plastik sampel, kemudian digoyang-goyangkan 
Tabel 1. Lokasi pengambilan sampel daun jeruk di Pulau Jawa

\begin{tabular}{|c|c|c|c|c|}
\hline Lokasi & Kota/Kabupaten & Desa/Kecamatan & Titik koordinat lokasi & $\begin{array}{c}\text { Ketinggian } \\
(\mathrm{m} \mathrm{dpl})\end{array}$ \\
\hline \multirow[t]{14}{*}{ Jawa Barat } & \multirow[t]{3}{*}{ Bogor } & Cikabayan/Dramaga & $6^{\circ} 33^{\prime} 02.7^{\prime \prime} \mathrm{LS}-106^{\circ} 43^{\prime} 12.5^{\prime \prime} \mathrm{BT}$ & 192 \\
\hline & & Cikabayan/Dramaga & $6^{\circ} 33^{\prime} 06.7^{\prime \prime} \mathrm{LS}-106^{\circ} 42^{\prime} 57.0^{\prime \prime} \mathrm{BT}$ & 195 \\
\hline & & Situ Gede/Bogor Barat & $6^{\circ} 32^{\prime} 42.6^{\prime \prime} \mathrm{LS}-106^{\circ} 44^{\prime} 27.5^{\prime \prime} \mathrm{BT}$ & 213 \\
\hline & \multirow[t]{2}{*}{ Ciamis } & Sadapaingan/Panawangan & $7^{\circ} 03^{\prime} 22.8^{\prime \prime} \mathrm{LS}-108^{\circ} 21^{\prime} 45.6^{\prime \prime} \mathrm{BT}$ & 540 \\
\hline & & Sadapaingan/Panawangan & $7^{\circ} 03^{\prime} 08.4^{\prime \prime} \mathrm{LS}-108^{\circ} 21^{\prime} 26.0^{\prime \prime} \mathrm{BT}$ & 550 \\
\hline & Cianjur & Cikaruya/Warung Kondang & $6^{\circ} 52^{\prime} 46.4^{\prime \prime} \mathrm{LS}-107^{\circ} 06^{\prime} 38.8^{\prime \prime} \mathrm{BT}$ & 533 \\
\hline & \multirow[t]{3}{*}{ Garut } & Cibolerang/Karang Pawitan & $7^{\circ} 11^{\prime} 03.3^{\prime \prime} \mathrm{LS}-107^{\circ} 57^{\prime} 00.5^{\prime \prime} \mathrm{BT}$ & 713 \\
\hline & & Mekar Sari/Pasir Wangi & $7^{\circ} 14^{\prime} 10.8^{\prime \prime} \mathrm{LS}-107^{\circ} 50^{\prime} 49.8^{\prime \prime} \mathrm{BT}$ & 895 \\
\hline & & Rancabeet/Samarang & $7^{\circ} 12^{\prime} 37.5^{\prime \prime} \mathrm{LS}-107^{\circ} 49^{\prime} 34.3^{\prime \prime} \mathrm{BT}$ & 1000 \\
\hline & Kuningan & Kalimanggis/Kalimanggis & $6^{\circ} 58^{\prime} 24.9 ” \mathrm{LS}-108^{\circ} 36^{\prime} 40.3 ” \mathrm{BT}$ & 193 \\
\hline & Majalengka & Giri Mulya/Banyaran & $6^{\circ} 57^{\prime} 01.0^{\prime \prime} \mathrm{LS}-108^{\circ} 18^{\prime} 24.6^{\prime \prime} \mathrm{BT}$ & 724 \\
\hline & \multirow[t]{2}{*}{ Sukabumi } & Sukalarang/Sukalarang & $6^{\circ} 52^{\prime} 57.0^{\prime \prime} \mathrm{LS}-107^{\circ} 00^{\prime} 40.8^{\prime \prime} \mathrm{BT}$ & 880 \\
\hline & & Semplak/Sukalarang & $6^{\circ} 54^{\prime} 59.1^{\prime \prime} \mathrm{LS}-107^{\circ} 00^{\prime} 06.8^{\prime \prime} \mathrm{BT}$ & 713 \\
\hline & Sumedang & Paseh Kaler/Paseh & $6^{\circ} 47^{\prime} 47.9^{\prime \prime} \mathrm{LS}-108^{\circ} 00^{\prime} 27.0^{\prime \prime} \mathrm{BT}$ & 492 \\
\hline \multirow[t]{2}{*}{ Jawa Tengah } & Pati & Payang/Pati & $6^{\circ} 43^{\prime} 49.4^{\prime \prime} \mathrm{LS}-111^{\circ} 03^{\prime} 55.5^{\prime \prime} \mathrm{BT}$ & 30 \\
\hline & Wonogiri & Blimbing/Manyaran & $7^{\circ} 51 ' 19.9 ” \mathrm{LS}-110^{\circ} 47^{\prime} 23.5^{\prime \prime} \mathrm{BT}$ & 246 \\
\hline \multirow[t]{8}{*}{ Jawa Timur } & Jombang & Menturus/Kudu & $7^{\circ} 26^{\prime} 39.0^{\prime \prime} \mathrm{LS}-112^{\circ} 18^{\prime} 56.2^{\prime \prime} \mathrm{BT}$ & 31 \\
\hline & \multirow[t]{3}{*}{ Mojokerto } & Jatijejer/Trawas & $7^{\circ} 37^{\prime} 16.9^{\prime \prime} \mathrm{LS}-112^{\circ} 34^{\prime} 07.0^{\prime \prime} \mathrm{BT}$ & 433 \\
\hline & & Rejosari/Ngadirejo & $7^{\circ} 51^{\prime} 20.3 " \mathrm{LS}-111^{\circ} 06^{\prime} 53.3 " \mathrm{BT}$ & 316 \\
\hline & & Kedung Sari/Kemligi & $7^{\circ} 27^{\prime} 11.7^{\prime \prime} \mathrm{LS}-112^{\circ} 20^{\prime} 56.4^{\prime \prime} \mathrm{BT}$ & 42 \\
\hline & Malang & Brombongan/Pakis & $7^{\circ} 56 ’ 32.2^{\prime \prime} \mathrm{LS}-112^{\circ} 41^{\prime} 44.0^{\prime \prime} \mathrm{BT}$ & 513 \\
\hline & \multirow[t]{2}{*}{ Pacitan } & Sumber Rejo/Jatisrono & $7^{\circ} 51^{\prime} 26.4^{\prime \prime} \mathrm{LS}-111^{\circ} 06^{\prime} 50.8^{\prime \prime} \mathrm{BT}$ & 314 \\
\hline & & Ndolo Kidul/Punung & $8^{\circ} 07^{\prime} 47.9^{\prime \prime} \mathrm{LS}-111^{\circ} 02^{\prime} 09.4^{\prime \prime} \mathrm{BT}$ & 448 \\
\hline & Tulung Agung & Pulosari/Punut & $8^{\circ} 05^{\prime} 48.6^{\prime \prime} \mathrm{LS}-111^{\circ} 59^{\prime} 38.9^{\prime \prime} \mathrm{BT}$ & 105 \\
\hline
\end{tabular}

supaya tungau terlepas dari daun, setelah itu dipindahkan ke dalam vial dan diberi label. Tungau dikelompokkan berdasarkan kemiripan morfologi, kemudian dihitung komposisi jumlahnya.

\section{Identifikasi dan koleksi}

Identifikasi jenis tungau dilakukan di Laboratorium Ekologi Serangga, Departemen Proteksi Tanaman, Fakultas Pertanian, IPB University, Balai Besar Uji Standar Karantina
Pertanian, dan Balai Besar Karantina Pertanian Tanjung Priok.

Identifikasi tungau diawali dengan proses mounting untuk mendapatkan spesimen yang dapat diamati di bawah mikroskop compound. Tahapan proses mounting menggunakan metode Zhang (2003). Identifikasi tungau berdasarkan karakteristik morfologi dilakukan di bawah mikroskop compound dengan perbesaran 2001000X dengan menggunakan kunci identifikasi 
yang sesuai, yakni Fan \& George (2012); Gerson et al. (1999); Keifer (1938); Miller (1966); Muma (1964); Qin (2001); Vacante (2010); Welbourn et al. (2003); Zhang et al. (2002); Zhang (2003).

\section{HASIL}

\section{Keanekaragaman tungau pada tanaman jeruk di Pulau Jawa}

Spesies tungau yang ditemukan berasosiasi dengan tanaman jeruk di Pulau Jawa adalah $B$. phoenicis, Eotetranychus sp., Eutetranychus sp., Tarsonemus bilobatus Suski, Ph. oleivora, P. citri, Amblyseius sp., dan Cheletogenes ornatus (Canestrini \& Fanzago). Selain itu, terdapat jenis tungau yang belum teridentifikasi dan merupakan Famili Tydeidae dan Winterschmidtiidae (Tabel 2). Tungau yang bersifat fitofag antara lain Famili Tetranychidae ( $P$. citri, Eotetranychus sp., Eutetranychus sp.), Tenuipalpidae (B. phoenicis), Tarsonemidae ( $T$. bilobatus), Eriophyidae (Ph. oleivora), dan Tydeidae. Tungau kelompok predator adalah Famili Phytoseiidae (Amblyseius sp.), Cheyletidae (C. ornatus), dan Winterschmidtiidae. Famili-famili tersebut tergolong dalam tiga subordo yang berbeda, yaitu Prostigmata (Tetranychidae, Tenuipalpidae, Tarsonemidae,

Tabel 2. Jenis tungau pada berbagai jenis jeruk di Pulau Jawa

\begin{tabular}{|c|c|c|c|c|}
\hline $\begin{array}{l}\text { Famili } \\
\text { Spesies }\end{array}$ & Peran & Jenis jeruk & Kabupaten/kota & $\begin{array}{l}\text { Jumlah } \\
\text { individu }\end{array}$ \\
\hline \multicolumn{5}{|l|}{ Eriophyidae } \\
\hline Phyllocoptruta oleivora & Fitofag & $\begin{array}{l}\text { Jeruk lemon, limau, } \\
\text { nipis, pamelo, purut, } \\
\text { siam }\end{array}$ & $\begin{array}{l}\text { Bogor, Ciamis, Cianjur, Sukabumi, } \\
\text { Sumedang, Majalengka, Jombang, } \\
\text { Malang, Mojokerto, Pacitan, Pati, } \\
\text { dan Tulung Agung }\end{array}$ & 6.670 \\
\hline \multicolumn{5}{|l|}{ Tarsonemidae } \\
\hline Tarsonemus bilobatus & Fitofag & Jeruk nipis & Ciamis & 17 \\
\hline \multicolumn{5}{|l|}{ Tenuipalpidae } \\
\hline Brevipalpus phoenicis & Fitofag & $\begin{array}{l}\text { Jeruk lemon, limau, } \\
\text { pamelo, purut, siam }\end{array}$ & $\begin{array}{l}\text { Bogor, Ciamis, Kuningan, } \\
\text { Sukabumi, Sumedang, Malang, } \\
\text { Mojokerto, Tulung Agung, Pacitan, } \\
\text { dan Wonogiri }\end{array}$ & 588 \\
\hline \multicolumn{5}{|l|}{ Tetranychidae } \\
\hline Panonychus citri & Fitofag & $\begin{array}{l}\text { Jeruk keprok garut, } \\
\text { keprok konde, lemon, } \\
\text { limau, nipis, pamelo, } \\
\text { siam, purut }\end{array}$ & $\begin{array}{l}\text { Bogor, Ciamis, Cianjur, Garut, } \\
\text { Kuningan, Majalengka, Sukabumi, } \\
\text { Sumedang, Malang, Jombang, } \\
\text { Mojokerto, Pacitan, Tulung Agung, } \\
\text { Pati, dan Wonogiri }\end{array}$ & 1.637 \\
\hline Eotetranychus sp. & Fitofag & $\begin{array}{l}\text { Jeruk lemon, limau, } \\
\text { nipis, pamelo, siam }\end{array}$ & $\begin{array}{l}\text { Bogor, Cianjur, Majalengka, } \\
\text { Jombang, Malang, Mojokerto, dan } \\
\text { Pacitan }\end{array}$ & 57 \\
\hline Eutetranychus sp. & Fitofag & Jeruk pamelo & Malang & 7 \\
\hline Tydeidae & Fitofag & Jeruk nipis, pamelo & Ciamis, Mojokerto, dan Pacitan & 15 \\
\hline \multicolumn{5}{|l|}{ Phytoseiidae } \\
\hline Amblyseius sp. & Predator & $\begin{array}{l}\text { Jeruk limau, nipis, } \\
\text { jeruk pamelo }\end{array}$ & $\begin{array}{l}\text { Bogor, Sukabumi, Sumedang, } \\
\text { Jombang, Malang, Tulung Agung }\end{array}$ & 21 \\
\hline \multicolumn{5}{|l|}{ Cheyletidae } \\
\hline Cheletogenes ornatus & Predator & Jeruk limau, nipis & Jombang dan Pacitan & 3 \\
\hline Winterschmidtiidae & Predator & Jeruk siam & Ciamis & 2 \\
\hline
\end{tabular}


Eriophyidae, Tydeidae, dan Cheyletidae), Mesostigmata (Phytoseiidae), dan Astigmata (Winterschmidtiidae). Selain pengambilan sampel daun, pada penelitian ini juga diamati beberapa sampel ranting muda dan buah, terlihat adanya spesies $P$. citri pada buah jeruk keprok garut.

Komposisi jenis tungau pada pertanaman jeruk yang dominan adalah Famili Eriophyidae (74\%). Famili lainnya, yaitu Tetranychidae, Tenuipalpidae, Phytoseiidae, Tarsonemidae, Tydeidae, Cheyletidae, dan Winterschmidtiidae masing-masing secara bertutur-turut adalah sebesar $19 \%, 7 \%, 0,23 \%, 0,19 \%, 0,17 \%, 0,03 \%$, dan $0,02 \%$ (Gambar 1). Sementara itu, jumlah individu spesies tertinggi yang ditemukan adalah Ph. oleivora (Tabel 2).

\section{Deskripsi spesies tungau pada daun tanaman jeruk}

Brevipalpus phoenicus (Geijskes). $B$. phoenicis (Famili Tenuipalpidae) ditemukan pada jeruk lemon, limau, nipis, purut, dan siam disepuluh lokasi tersebar di Jawa Barat, Jawa Tengah, dan Jawa Timur. Tersebar di lokasi temuan yang antara lain di Bogor, Sumedang, Wonogiri, dan Malang, dan sebanyak 588 individu berhasil dikoleksi (Tabel 2). Tungau ini mempunyai bentuk tubuh yang pipih (flat); pada bagian hysterosoma memiliki dua lubang opistosoma (opisthosomal pore); tarsus II memiliki 2 solenidia; pola kutikula pada prodorsum, yaitu areolae; pada bagian hysterosoma terdapat 6 pasang seta dorsolateral (dorsolateral setae) (c3, d3, e3, f3, h2, dan h1); pola kutikula pada area e1-e1 sampai h1-h1 selalu dengan pola kerutan kuat yang membentuk pola $\mathrm{V}$, kemudian makin lemah ketika mengarah ke area h1-h1 (Gambar 2A-D).

\section{Famili Tetranychidae (Eotetranychus} sp., Eutranychus sp., dan Panonychus citri McGregor. Tungau Eotetranychus sp. diperoleh dengan komposisi jumlah sebanyak 57 individu dan ditemukan pada tujuh lokasi pengambilan sampel dengan kisaran jenis jeruk yang beragam, kecuali pada jeruk keprok garut, purut, dan konde (Tabel 2). Karakter penting morfologinya, yaitu pada bagian pelat anal memiliki dua pasang seta anal (as1-2) dan dua pasang seta para-anal (ps12); pada tarsus I terdapat dua seta dupleks; dan penciri utama genus ini, yaitu pada ujung tarsus memiliki tiga pasang rambut proksimoventral dan tidak memiliki claw (Gambar 3A-B).

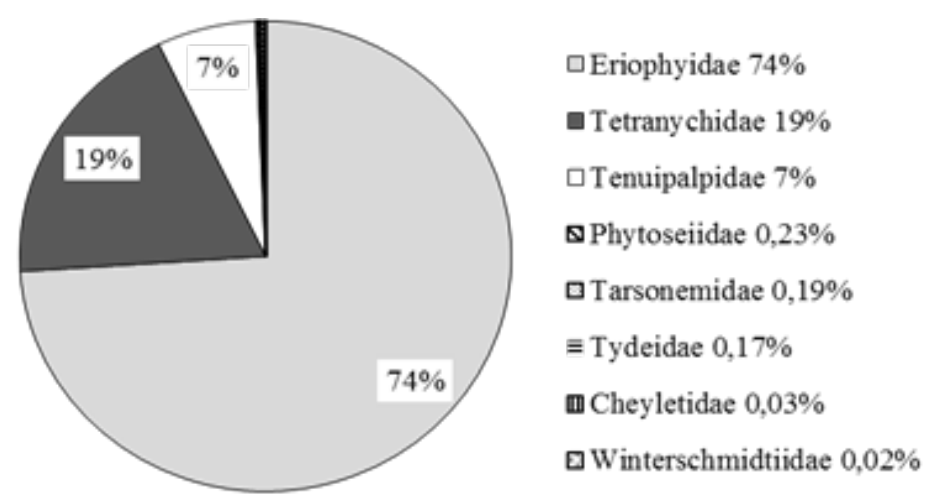

Gambar 1. Komposisi famili tungau pada pertanaman jeruk di Pulau Jawa.
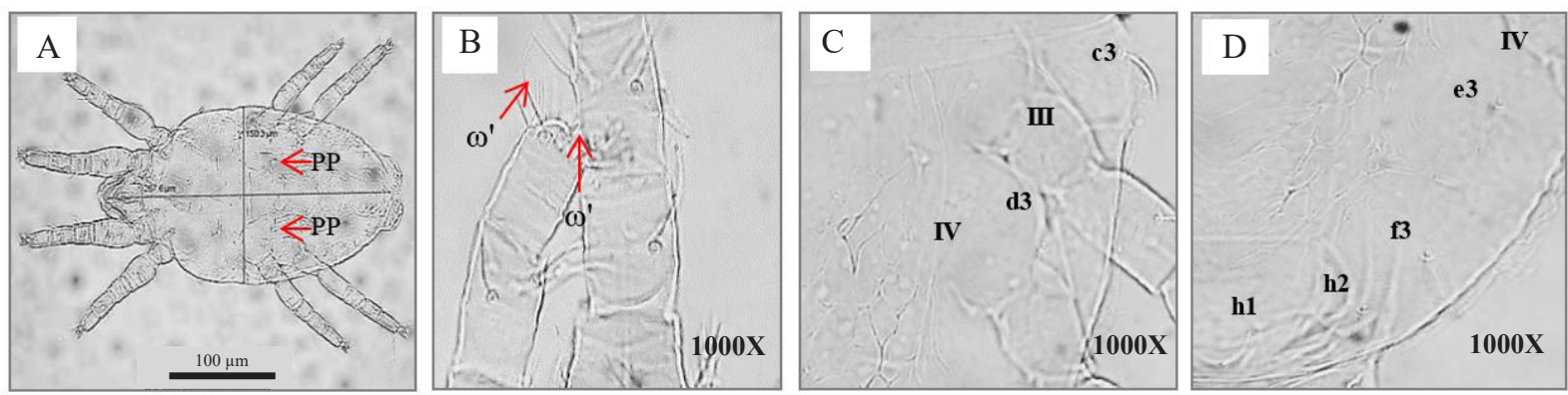

Gambar 2. Ciri morfologi untuk identifikasi Brevipalpus phoenicis: A: bagian dorsal betina dengan lubang opistosoma (PP); B: tarsus II memiliki dua solenidia ( $\left.\omega^{\prime}\right)$; C dan D: hysterosoma dengan enam pasang seta dorsolateral (c3, d3, e3, f3, h2, dan h1). 
Eutetranychus sp. hanya ditemukan di Kabupaten Malang pada buah jeruk pamelo, dengan jumlah hanya 7 individu (Tabel 2). Karakter penting morfologi Eutetranycus sp., yaitu propodosoma memiliki tiga pasang seta dorsal $\left(\mathrm{v}_{2}\right.$, $\mathrm{sc} 1, \mathrm{sc} 2)$; bagian hysterosoma memiliki 10 pasang seta (c1-3, d1\&3, e1\&3, f1, h1-2,); pada pelat anal terdapat dua pasang seta anal (as1-2) dan dua seta para-anal (ps1-2); tibia II memiliki enam seta; pada tarsus I terdapat satu solenidia dan empodium tanpa kuku (claw) (Gambar 3C-F).

Komposisi jumlah spesies $P$. citri sebesar 1.637 individu dari total sampel, dan tungau ini ditemukan pada semua jenis tanaman jeruk dan semua lokasi pengambilan sampel (Tabel 2). Karakter penting morfologinya antara lain memiliki tuberkel dan seta dorsal berwarna merah, serta seta pada bagian dorsal menempel pada struktur tuberkel yang kokoh; pada pelat anal (anal plate) terdapat dua pasang seta anal (anal setae) (as1-2) dan dua seta para-anal (para-anal setae) (ps1-2); tarsus I memiliki dua pasang seta dupleks (duplex setae); ujung tarsus memiliki kuku empodium (empodium claw) dan tiga pasang rambut proksimoventral (proximoventral hairs); pada bagian femur I terdapat delapan seta; pada ujung opisthosoma memiliki seta klunal (clunal setae) (h1) yang hampir sama panjang dengan seta sakral luar (outer sacral setae) (f2), sedangkan panjang $\mathrm{f} 2$ mendekati sepertiga panjang seta sakral dalam (inner sacral setae) (f1) (Gambar 3G-J).

Tarsonemus bilobatus Suski. Spesies $T$. bilobatus diperoleh sebanyak 17 individu pada tanaman jeruk nipis di Kabupaten Ciamis (Tabel 2). Spesies ini mengalami reduksi ukuran pada tungkai IV dari tungkai lainnya sebagai penciri utama dari Famili Tarsonemidae, femur dan gena menyatu, kemudian panjang tegula normal dengan panjang kurang dari 1,5 kali lebar dasar tegula; pada bagian propodosomal ventral terdapat apodeme (ap), posternal apodeme (pa), dan sejugal apodeme melekuk di tengah; metapodosomal ventral memiliki dua pasang seta ( $3 \mathrm{a}$ dan $3 \mathrm{~b}$ ), apodeme 4 (ap4) tidak melampaui dasar dari seta 3b. (Gambar 4).

Phyllocoptruta oleivora (Ashmead). Jenis tungau yang paling dominan ditemukan di lokasi pengambilan sampel, yaitu $P h$. oleivora (Famili
Eriophyidae) sebanyak 6.670 individu dan diperoleh dari hampir semua jenis jeruk dan lokasi pengambilan sampel, kecuali di Kabupaten Garut dan Kuningan (Tabel 2). Karakter morfologi yang utama antara lain pada bagian dorsal memiliki 31 annuli dan bentuk annulus terlihat melengkung ke dalam; empodium dengan 5 bulu-bulu kuku (featherclaw 5-rayed); bentuk perisai pada prodorsal, seperti bentuk jaring (Gambar 5).

\section{Famili Phytoseiidae (Amblyseius sp.)}

Amblyseius sp. merupakan tungau predator dengan jumlah sebanyak 21 individu (Tabel 2). Tungau ini hanya ditemukan di beberapa lokasi pengambilan sampel, antara lain Bogor, Sukabumi, Sumedang, Jombang, Malang, dan Tulung Agung (Tabel 2). Ukuran tungkai I tungau ini sedikit lebih panjang dari tungkai II; bagian dorsal memiliki satu perisai punggung (dorsal shield), bagian ventral terdapat empat perisai (shields) (perisai sternal/ sternal shield, perisai metasternal/metasternal shield, perisai epiginal/epigynal shiled, dan perisai ventrianal/ventrianal shield); stigma berada di antara coxa III dan IV, dan peritreme biasanya mengerah ke depan; perisai metasternal kecil, tidak menyatu dengan perisai epiginal dan seta sternal (sternal setae 4) (st4) terletak pada perisai metasternal; palpaltarsal memiliki dua apotele; tarsus I berakhir pada sepasang kuku; pada bagian perisai prodorsal (prodorsol shield) memiliki empat pasang seta lateral (L1-4); baris basal pada deutosternal denticle sempit, dan tidak meluas keluar dari dasar seta kapitular (capitular setae); perisai ventrianal memiliki tiga pasang seta pre-anal (pre-anal setae) (1-3), dua lubang preanal (pre-anal pore), satu pasang seta para-anal (Gambar 6).

Famili Cheyletidae (Cheletogenes ornatus (Canestrini \& Fanzago)). Jenis tungau predator lainnya, yaitu $C$. ornatus yang ditemukan Jombang dan Pacitan pada jeruk limau dan jeruk nipis dengan jumlah sebanyak 3 individu (Tabel 2). Karakter penting morfologinya memiliki tubuh yang mendekati bulat dan pendek, perisai tubuh bagian dorsal memiliki kerutan yang kuat; tungkai I memiliki seta terminal yang panjangnya hampir sama dengan panjang tungkai, tibia I lebih panjang dari tarsus I; tarsus I memiliki satu solenidia, seperti pasak; tarsus II-IV memiliki kuku yang halus dan 

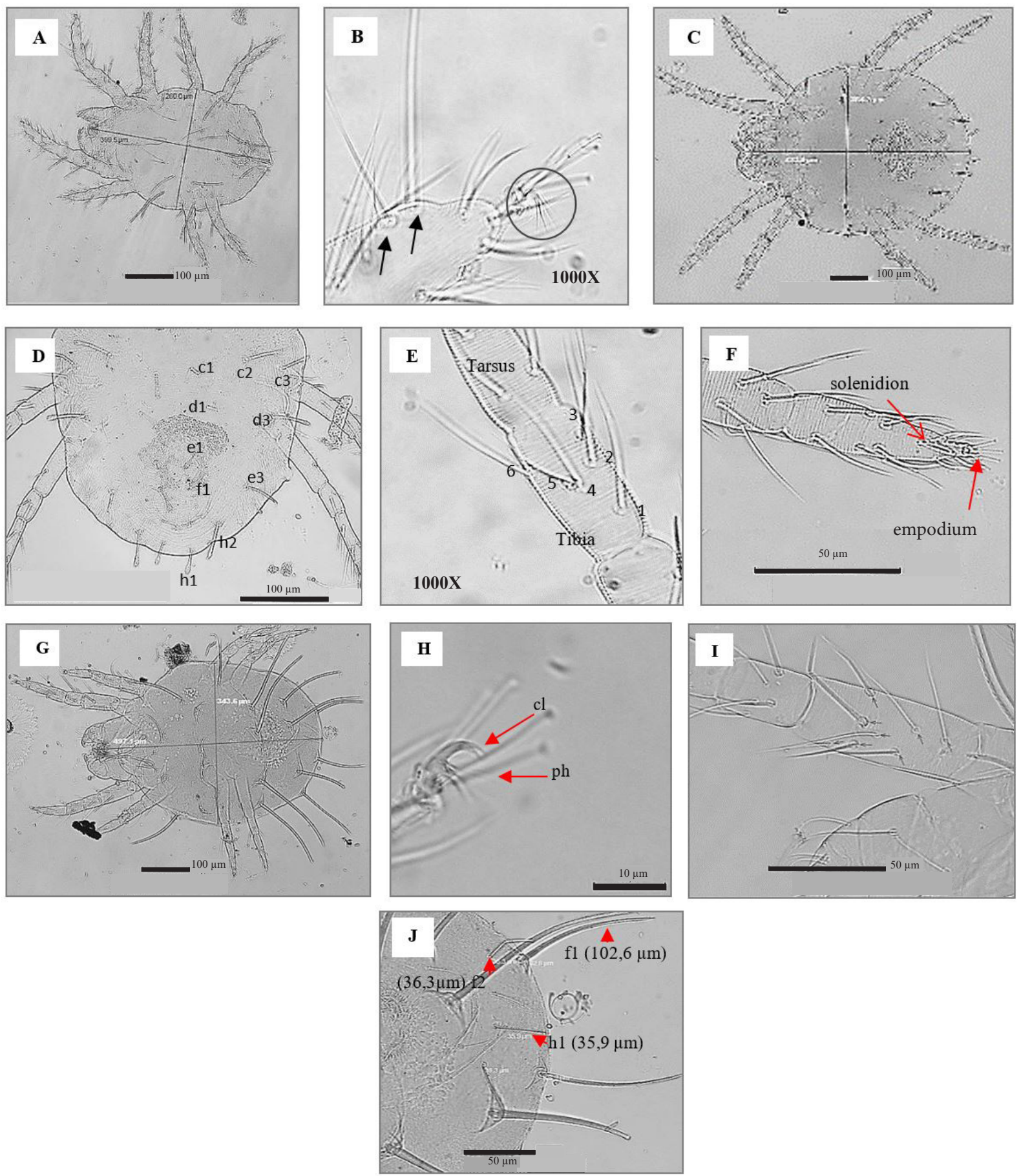

Gambar 3. Ciri morfologi untuk identifikasi tungau dari Famili Tetranychidae. A: bagian dorsal betina Eotetranycus sp.; B: ujung tarsus memiliki 3 pasang rambut proksimoventral, tarsus I terdapat 2 seta dupleks; C: bagian dorsal betina Eutetranycus sp.; D: pada hysterosoma memiliki 10 pasang seta (c1-3, d1\&3, e1\&3, f1, h1-2); E: tibia II memiliki 6 seta; F: pada tarsus I terdapat 1 solenidia dan empodium tanpa kuku; G: bagian dorsal Panonychus citri, seta menempel pada tuberkel yang kokoh; H: kuku empodium (cl) memilki tiga pasang rambut proksimoventral; I: femur I memiliki 8 seta; J: hysterosoma memiliki seta klunal (h1) yang sama panjang dengan seta sakral luar (f2); f2 mendekati sepertiga panjang seta sakral dalam (f1). 

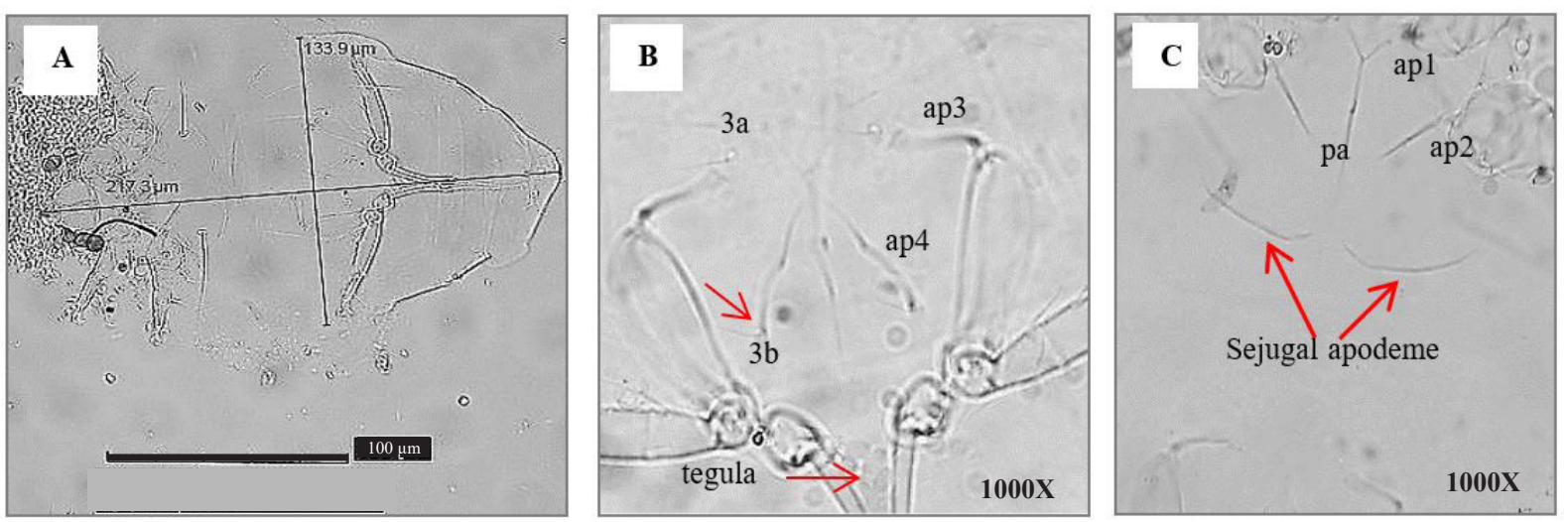

Gambar 4. Ciri morfologi untuk identifikasi Tarsonemus bilobatus: A: tungkai IV imago mengalami reduksi dari tungkai lainnya, femur dan gena menyatu; B: metapodosomal ventral memiliki dua pasang seta (3a dan 3b), apodeme 4 (ap4) tidak melampaui dasar dari seta 3b, panjang tegula normal yang panjang kurang dari 1,5 kali lebar dasarnya; C: apodeme (ap), posternal apodeme (pa), sejugal apodeme melekuk di tengah.
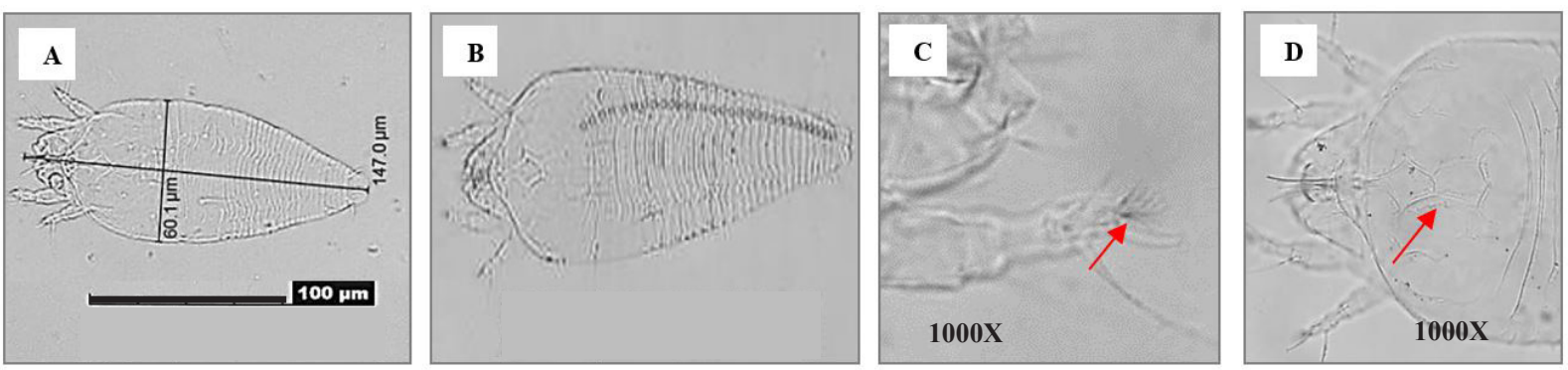

Gambar 5. Ciri morfologi untuk identifikasi Phyllocoptruta oleivora: A: bagian dorsal imago; B: 31 annuli pada bagian dorsal dan bentuk annulus melengkung ke dalam; C: empodium dengan lima bulubulu kuku; D: bentuk perisai pada prodorsal.
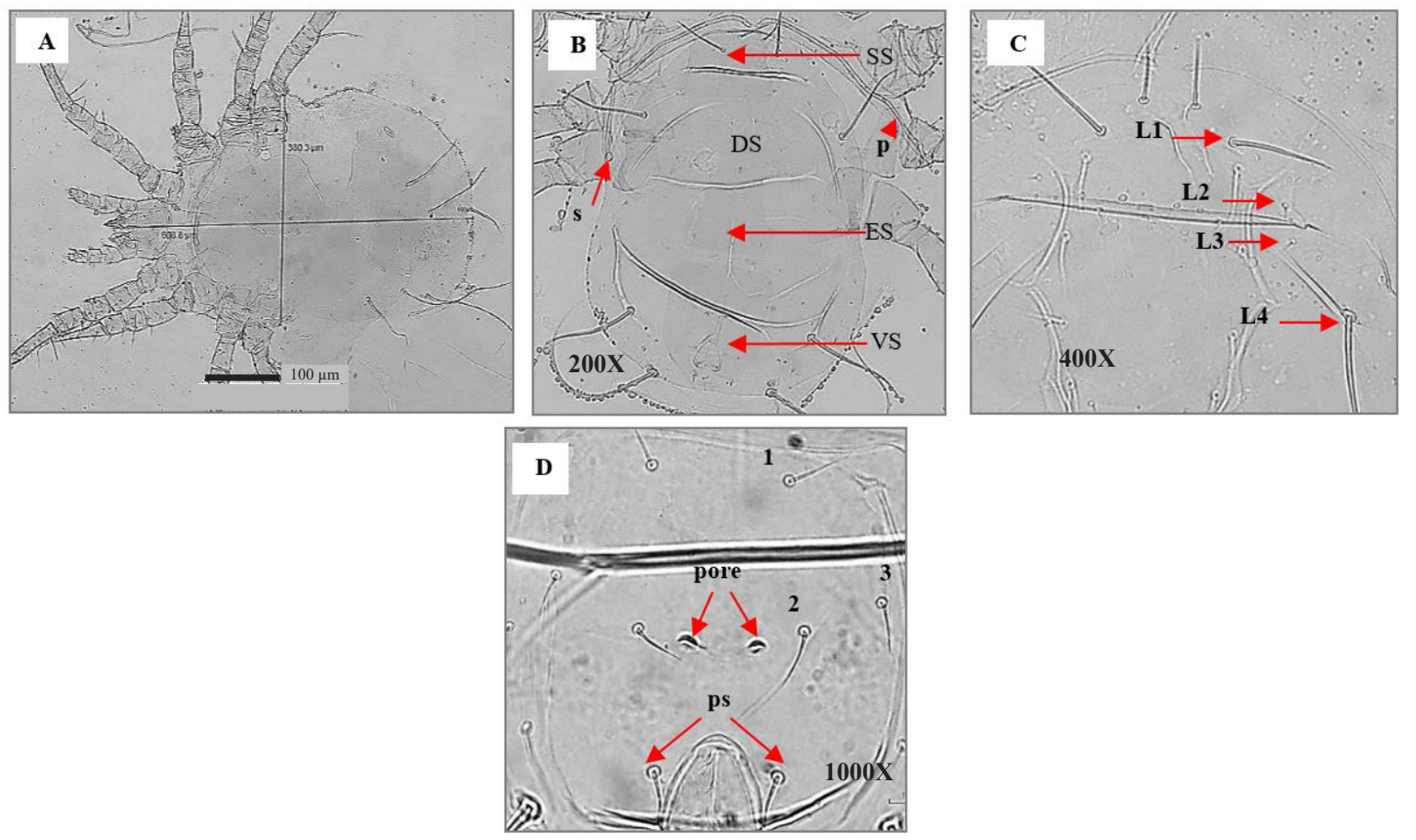

Gambar 6. Ciri morfologi untuk identifikasi tungau Amblyseius sp. A: bagian dorsal; B: bagian dorsal memiliki satu perisai punggung (DS), bagian ventral terdapat empat perisai sterna (SS), perisai metasternal, perisai epiginal (ES), dan perisai ventrianal (VS), stigma (s) berada di antara coxa III dan IV, peritreme (p) biasanya mengerah ke depan, C: bagian perisai prodorsal memiliki empat pasang seta lateral, D: perisai ventri anal memiliki tiga pasang seta pre-anal (1-3), dua lubang pre-anal (preanal pore), satu pasang seta para-anal (ps). 
empodia; pola pada perisai rostral (rostral shield), yaitu striate (seperti sidik jari); tarsus pada palpus memiliki dua seta seperti sisir dan dua seta, seperti sabit; kuku pada palpus dengan lebih dari tiga gigi (Gambar 7).

Famili Tydeidae. Jenis tungau termasuk Famili Tydeidae pada daun tanaman jeruk ini hanya dapat diidentifikasi sampai tingkatan famili dan ditemukan sebanyak 15 individu di Pacitan, Ciamis, dan Mojokerto pada tanaman jeruk nipis dan pamelo (Tabel 2). Spesies ini mempunyai kelisera berdekatan satu sama lain; pada bagian palpaltarsus dan tarsus I tidak berujung dengan kuku; pola pada bagian ventral gnathosoma, yaitu striate; tarsus II-IV berujung dengan sepasang kuku. Karakter penting morfologi tersebut tertera pada Gambar 8.

Famili Winterschmidtiidae. Satu spesies dalam Famili Winterschmidtiidae hanya ditemukan pada jeruk siam di Ciamis. Karakter dari famili ini, yaitu apodemes coxae I dan II tidak menyatu di bagian tengah; seta vi dekat ke tepi anterior
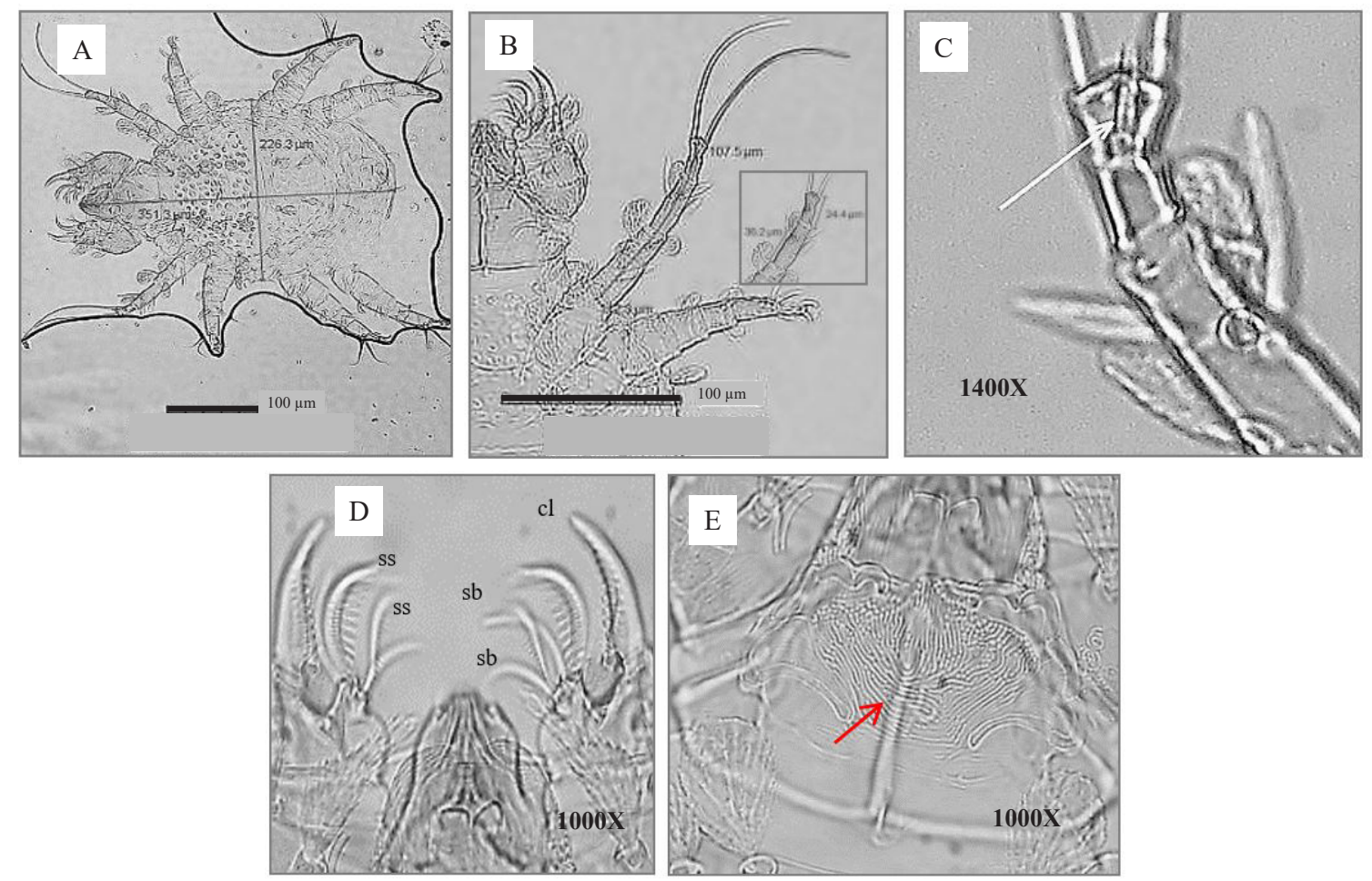

Gambar 7. Ciri morfologi untuk identifikasi tungau Cheletogenes ornatus. A: betina memiliki tubuh yang mendekati bulat dan pendek, perisai tubuh bagian dorsal memiliki kerutan yang kuat; B: tungkai I memiliki terminal seta yang panjangnya hampir sama dengan panjang tungkai dan tibia I lebih panjang dari tarsus I, tarsus II-IV memiliki kuku yang halus dan empodia; C: tarsus I memiliki satu solenidia seperti pasak; D: tarsus pada palpus memiliki dua seta seperti sisir (ss) dan dua seta seperti sabit (sb); kuku (cl) pada palpus dengan lebih dari tiga gigi; E: pola pada perisai rostral, yaitu striate (seperti sidik jari).
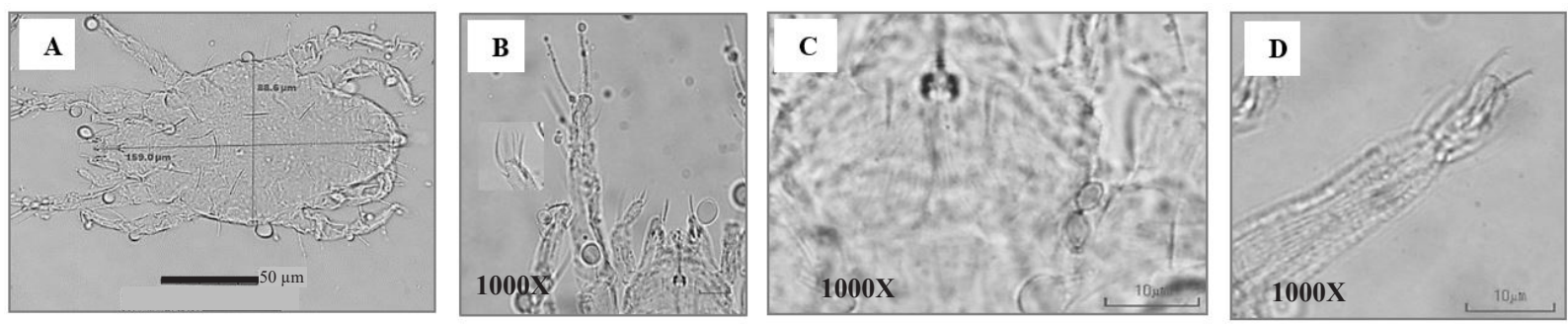

Gambar 8. Ciri morfologi untuk identifikasi tungau dari Famili Tydeidae. A: bagian dorsal; B: palpaltarsus dan tarsus I tidak berujung dengan kuku; C: pola pada bagian gnathosoma ventral, yaitu striate; D: tarsus II-IV berujung dengan sepasang kuku. 
prodorsum; tarsi dengan kuku empodial (empodial claw); condylophores berbentuk Y; tibia I dan II masing-masing memiliki 1-2 seta. Ciri morfologi tersebut tertera pada Gambar 9.

\section{PEMBAHASAN}

Spesies Ph. oleivora (citrus rust mite) diketahui sejak tahun 1879 di Florida dan sampai saat ini dapat ditemukan pada pertanaman jeruk di seluruh dunia (Keifer et al. 1982). Tungau ini menyebabkan kerusakan permukaan daun, sel epidermis buah, serta ranting yang masih hijau (Futch et al. 2001; CABI 2014a). Pada kulit jeruk, daun dan ranting menyebabkan russeting dan bronzing serta menjadi salah satu hama yang menyebabkan kerusakan paling banyak di Florida dan Texas, sedangkan di California menjadi hama yang lebih serius pada lemon (Keifer et al. 1982). Jenis jeruk yang menjadi inang $P h$. oleivora antara lain jeruk manis (C. sinensis), lemon (C. limonia), jeruk nipis $(C$. aurantiifolia), jeruk pamelo $(C$. maxima), dan anggota jeruk lainnya (Citrus spp.) (Keifer 1952; CABI 2014b). Menurut Pementan Nomor 31 Tahun 2018 tentang Jenis Organisme Pengganggu Tumbuhan Karantina, spesies ini masih dikategorikan OPT Karantina A1 yang keberadaannya belum terdapat di Indonesia. Menurut data CABI (2014b) penyebarannya di Asia kecuali Indonesia. Akan tetapi, Endarto (2004) telah melakukan survei mengenai kelimpahan populasi pada tanaman jeruk di kota Batu, Jawa Timur.

Kalshoven (1981) mendokumentasikan spesies tungau yang juga menyerang tanaman jeruk, yaitu daun muda (Tenuipalpus sp. atau red spider mite) dan kuncup muda (Aceria sheldoni (Ewing) atau citrus bud mite) dan buah (Tenuipalpus cuneatus (Canestrini \& Fanzago)) serta Eriophyes sp.

Temuan penelitian dan laporan sebelumnya menunjukkan $P h$. oleivora sudah tersebar di sebagian daerah di Pulau Jawa. Hal ini bisa dijadikan dasar pertimbangan untuk menurunkan statusnya menjadi OPT Karantina kategori A2 yang memiliki daerah persebaran terbatas di dalam wilayah Indonesia. Selanjutnya, tindakan pencegahan perlu dilakukan untuk membatasi semakin tersebarnya ke daerah lain dengan memperketat peredaran tanaman jeruk karena menurut CABI (2014b), tungau karat dapat bertahan pada tunas dan daun yang menggulung.

Selain Ph. oleivora, P. citri (citrus red mite) juga termasuk jenis tungau yang dikategorikan A2, artinya keberadaannya sudah pernah dilaporkan di Indonesia dengan penyebaran terbatas. Tungau ini menyerang daun tanaman inang (Qin 2001), dan merupakan hama yang serius pada tanaman jeruk di California, Afrika Selatan, dan Jepang. Ditemukan juga di Florida, Cina, Amerika Selatan, dan India. Selain pada tanaman jeruk, juga ditemukan pada almond, pear, dan tanaman hias berdaun lebar (Hoy 2011). Di Indonesia telah dilaporkan sebagai new report oleh Affandi (2007) pada tanaman jeruk mandarin di Balai Penelitian Tanaman Buah Tropika Solok. Selain pada jeruk mandarin, Puspitarini et al. (2012) juga melaporkan mengenai kelimpahan $P$. citri pada pertanaman apel di Malang.

Jenis tungau berikutnya yang memiliki komposisi jumlah cukup tinggi, yaitu B. phoenicis (reddish black flat mite). Tungau ini memiliki kisaran inang antara lain pohon palem (Baker 1949), teh (Widayat 2006; Komsiati 2008),
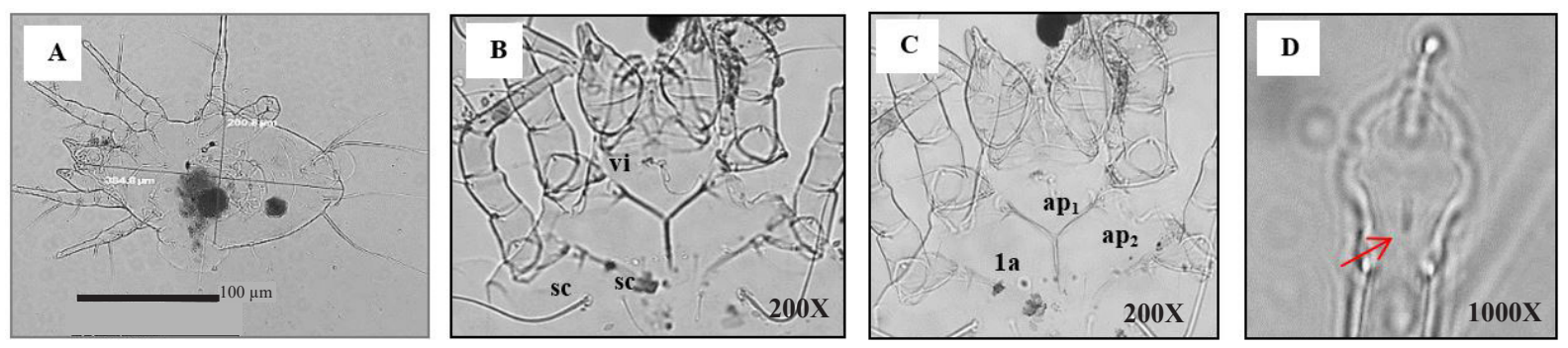

Gambar 9. Ciri morfologi untuk identifikasi tungau dari Famili Winterschmidtiidae. A: bagian dorsal; B: seta vi dekat ke tepi anterior prodorsum; C: apodemes coxae I ( $\left.\mathrm{ap}_{1}\right)$ dan II ( $\left.\mathrm{ap}_{2}\right)$ pada bagian ventral tidak menyatu di bagian tengah; D: tarsus memiliki condylophores berbentuk $\mathrm{Y}$ dan berujung dengan kuku empodial. 
pepaya, jeruk, dan markisa (Haramoto 1969). Daerah sebarannya sangat luas dan menjadi hama kosmopolitan di negara dengan iklim tropis (Haramoto 1969). Mengacu kepada Permentan Nomor 31 Tahun 2018 tentang Jenis Organisme Pengganggu Tumbuhan Karantina, spesies B. californicus merupakan OPTK A1, sebagian karakter morfologi yang menjadi pembeda antara lain jumlah dan bentuk seta pada bagian dorsolateral yang 7 pasang dan setiform (Baker 1949; Zhang 2003; Welbourn et al. 2003; Vacante 2010).

Tungau lain yang belum teridentifikasi, yaitu Eutetranychus sp. Salah satu spesiesnya, yaitu $E$. orientalis (inang utama adalah jeruk dan inang alternatif lainnya adalah pepaya, kapas, murbei, rambutan, dan terung) merupakan OPT yang dikategorikan sebagai OPT Karantina kategori A2 sesuai Permentan Nomor 31 Tahun 2018). Mengenai hal ini, perlu dilakukan pengamatan kembali terhadap keberadaan spesies Eutetranycus sp. untuk mengetahui sejauh mana tungau ini sudah berada di Indonesia.

Spesies tungau lainnya, yaitu T. bilobatus merupakan hama minor pada tanaman di dalam rumah kaca. Bersifat fitofag pada sejumlah bunga hias di Polandia dan juga bisa bersifat fungivorous (Zhang 2003). Data CABI (2008a) menyebutkan bahwa yang menjadi inang antara lain bawang putih, paprika, semangka, melon, mentimun, labu, tomat, sawi putih. Daerah penyebaran meliputi Asia (Jepang, Korea, Cina, dan India), Afrika (Mesir), dan Eropa (Hungaria, Itali, Polandia, Belarus, dan Ukraina) (Zhang 2003; CABI 2008b). Spesies ini telah dikarakterisasi ciri-ciri morfologi dan telah dipublikasikan namanya pada jurnal internasional (CIAT 2004; Lofego et al. 2005; Lotfollahi \& Irani-Nejad 2010). Keberadaannya di Indonesia belum diketahui dan belum pernah dilaporkan. Oleh karena itu, spesies T. bilobatus merupakan laporan baru (new report) bagi Indonesia.

Secara umum, populasi tungau dipengaruhi oleh curah hujan dan suhu dengan populasi tinggi ketika curah hujan turun dan suhu meningkat (Crooker 1985). Akan tetapi, data pendukung, seperti curah hujan dan suhu bulanan tidak disajikan dalam penelitian ini. Penelitian selanjutnya perlu mempertimbangkan fluktuasi faktor cuaca yang mungkin dapat mempengaruhi populasi tungau pada tanaman. Berdasarkan hasil temuan, data yang diperoleh dapat dijadikan masukan untuk Badan Karantina Pertanian dalam melakukan analisis resiko terhadap spesies $P h$. oleivora sehingga perlu pemantauan sebarannya di wilayah Indonesia serta tindakan pencegahan untuk membatasi penyebaran ke daerah lain dapat dimaksimalkan.

\section{KESIMPULAN}

Delapan spesies tungau berhasil diidentifikasi dari berbagai jenis daun tanaman jeruk di Pulau Jawa, enam spesies di antaranya bersifat fitofag meliputi P. citri, Eotetranychus sp., Eutetranychus sp., B. phoenicis, T. bilobatus, dan Ph. oleivora. Dua spesies lainnya bersifat predator, yaitu Amblyseius sp. dan C. ornatus. Jenis tungau lain yang belum teridentifikasi, yaitu dari Famili Tydeidae dan Winterschmidtiidae. Selain itu, ditemukan spesies $T$. bilobatus yang merupakan spesies temuan baru di Indonesia.

\section{UCAPAN TERIMA KASIH}

Penulis mengucapkan terima kasih kepada Badan Karantina Pertanian yang telah memberikan beasiswa pendidikan. Laboratorium Ekologi Serangga, IPB, yang telah memfasilitasi penelitian ini serta Laboratorium Karantina Tumbuhan Balai Besar Uji Standar Karantina Pertanian dan Balai Besar Karantina Pertanian Tanjung Priok yang telah mengijinkan penggunaan mikroskop untuk identifikasi.

\section{DAFTAR PUSTAKA}

Affandi. 2007. Identifikasi tungau fitofag dan predator jeruk mandarin pada berbagai fase tumbuh. Jurnal Hortikultura 17:81-87.

Baker EW. 1949. The Genus Brevipalpus (Acarina: Pseudoleptidae). The American Midland Naturalist 42:350-402. doi: https://doi. org/10.2307/2422013.

[BPS] Badan Pusat Statistik. 2021. Produksi Produksi Tanaman Buah-buahan Tahunan di Indonesia. 
Tersedia pada: www.bps.go.id [diunduh 18 Agustus 2021].

[CABI] CAB International. 2008a. Datasheets Cheletogenes ornatus. Tersedia pada: http:// www.cabi.org/cpc/datasheet/12679. [diunduh 17 Maret 2015].

[CABI] CAB International. 2008b. Datasheets Tarsonemus bilobatus. Tersedia pada: http:// www.cabi.org/cpc/datasheet/52791 [diunduh 17 Maret 2015].

[CABI] CAB International. 2014a. Crop Protection Compendium. Wallingford (UK).

[CABI] CAB International. 2014b. Datasheets Phyllocoptruta oleivora (citrus rust mite). Tersedia pada: http://www.cabi.org/cpc/ datasheet/41000 [diunduh 17 Maret 2015].

[CIAT] Centro Internacional de Agricultura Tropical. 2004. Integrated Pest and Disease Management in Major Agroecosystems. Project-PEI-Annual Report 2004. Palmira: System-Wide Programme on Integrated Pest Management.

Crooker A. 1985. Embryonic and juvenile development. Di dalam: Helle W, Sabelis MW (Eds.) Spider Mites: Their Biology, Natural Enemies, and Control. hlm. 149-163. Elsevier.

[Ditjen Horti] Direktorat Jendral HortikulturaKementerian Pertanian. 2014a. Profil Komoditas Jeruk. Tersedia pada: http://ditbuah. hortikultura.pertanian.go.id/admin/data/ PROFIL_JERUK.pdf [diunduh 5 Juni 2014].

[Ditjen Horti] Direktorat Jendral HortikulturaKementerian Pertanian. 2014b. Daerah Sentra Jeruk. Tersedia pada: http://hortikultura. pertanian.go.id/ [diunduh 5 Juni 2014].

Endarto O. 2004. Tungau Karat Jeruk (Acari: Eriophyidae) Kelimpahan Populasi, Tingkat Serangan, dan Persepsi Petani. Tesis. Bogor: Institut Pertanian Bogor.

Fan Qing-Hai, George S. 2012. Keys to Higher Taxa and Commonly Intercepted Families of Mites (ACARI). Plant Health \& Environment Laboratory. MPI. New Zealand. hlm 68-76.

Futch SH, Childers CC, McCoy CW. 2001. A Guide to Citrus Mite Identification. Tersedia pada: http://edis.ifas.ufl.edu. [diunduh 17 Maret 2015].

Gerson U, Fain A, Smiley RL. 1999. Further observations on the Cheyletidae (Acari), with a key to the genera of the Cheyletinae and a list of all known species in the family. Bulletin De L'institut Royal Des Sciences Naturelles De Belgique 69:35-86.

Haramoto FH. 1969. Biology and control of Brevipalpus phoenicis (Geijskes) (Acarina:
Tenuipalpidae). Technical Bulletin Hawaii Agricultural Experiment Station 68:63.

Hoy AM. 2011. Agricultural Acarology: Introduction to Integrated Mite Management. New York: CRC Press.

Kalshoven LGE. 1981. The Pests Crops in Indonesia. Laan PA Van Der, penerjemah. Jakarta: Ichtiar Baru-van Hoeve. Terjemahan dari: De Plagen Van De Culturagewasseen in Indonesia.

Keifer HH. 1938. Eriophid studies. California Department of Agriculture Bulletin 27:181-206.

Keifer HH. 1952. The Eriophyid mites of California. Bulletin of The California Insect Survey 2:53.

Keifer HH, Baker EW, Kono T, Delfinado M, Styer WE. 1982. An Illustrated Guide to Plant Abnormalities Caused by Eriophyid Mites in North America. Washington: United States Department of Agriculture.

Komsiati DA. 2008. Perkembangan Kelimpahan Setiap Stadium Brevipalpus phoenicis Geijskes di Perkebunan Teh Tanjungsari, Wonosobo Jawa Tengah. Skripsi. Purwekerto: Universitas Soedirman.

Lofego AC, Ochoa R, Morales GJ. 2005. Some tarsonemid mites (Acari: Tarsonemidae) from the Brazillian "Cerrado" vegetation, with descriptions of three new species. Zootaxa 823:1-27. doi: https://doi.org/10.11646/zootaxa.823.1.1.

Lotfollahi P, Irani-Nejad KH. 2010. New records of tarsonemid mites from alfalfa fields in northwest of East Azerbaijan Province, Iran (Acari). Munis Entomology \& Zoology 5:538-542.

Miller LW. 1966. The Tetranychid mites of Tasmania. Papers and Proceedings of the Royal Society of Tasmania 100:53-76.

Muma M. 1964. Cheyletidae (Acarina: Trombidiformes) associated with citrus in Florida. The Florida Entomol 47:239-253. doi: https://doi.org/10.2307/3493742.

Puspitarini RD, Affandhi A, Widyana A. 2012. Citrus red mite Panonychus citri (Mc.Gregor) (Acari: Tetranychidae) and other mites on apple plantation, Malang Indonesia. Asian Journal of Natural \& Applied Sciences 1:93-100.

Qin Tin-Kui. 2001. Acarology Training Manual with Special Reference to Mite Associated with Plant. Jakarta: Badan Karantina Pertanian.

Menteri Republik Indonesia. 2018. Peraturan Menteri Pertanian RI Nomor 31/Permentan/ KR.010/7/2018 tentang Perubahan Kedua Atas Peratiran Menteri Nomor 93/Permentan/ OT.140/12/2011 tentang Jenis Organisme Pengganggu Tumbuhan Karantina. Jakarta: RI. 
Vacante V. 2010. Citrus Mite: Identification, Bionomy and Control. Walingford: CABI Publishing Division of CABI Intn.

Welbourn WC, Ochoa R, Kane EC, Erbe EF. 2003. Morphological observations on Brevipalpus phoenicis (Acari: Tenuipalpidae) including comparisons with $B$. californicus and $B$. obovatus. Experimental \& Applied Acarology 30:107-133. doi: https://doi.org/10.1023/ B:APPA.0000006545.40017.a0.

Widayat W. 2006. Perkembangan Populasi Tungau Jingga (Brevipalpus phoenicis Geijskes) pada Beberapa Klon Teh. Tesis. Bandung: Institut Teknologi Bandung.
Zhang Zhi-Qiang, Henderson R, Flynn A, Martin N. 2002. Key to Tetranychidae of New Zealand. MAF Science Policy. Project FMA 180. London: CABI Publishing Division of CABI Intn.

Zhang Zhi-Qiang. 2003. Mite of Green House: Identification, Biology and Control. Walingford: CABI Publishing Division of CABI Intn. 